
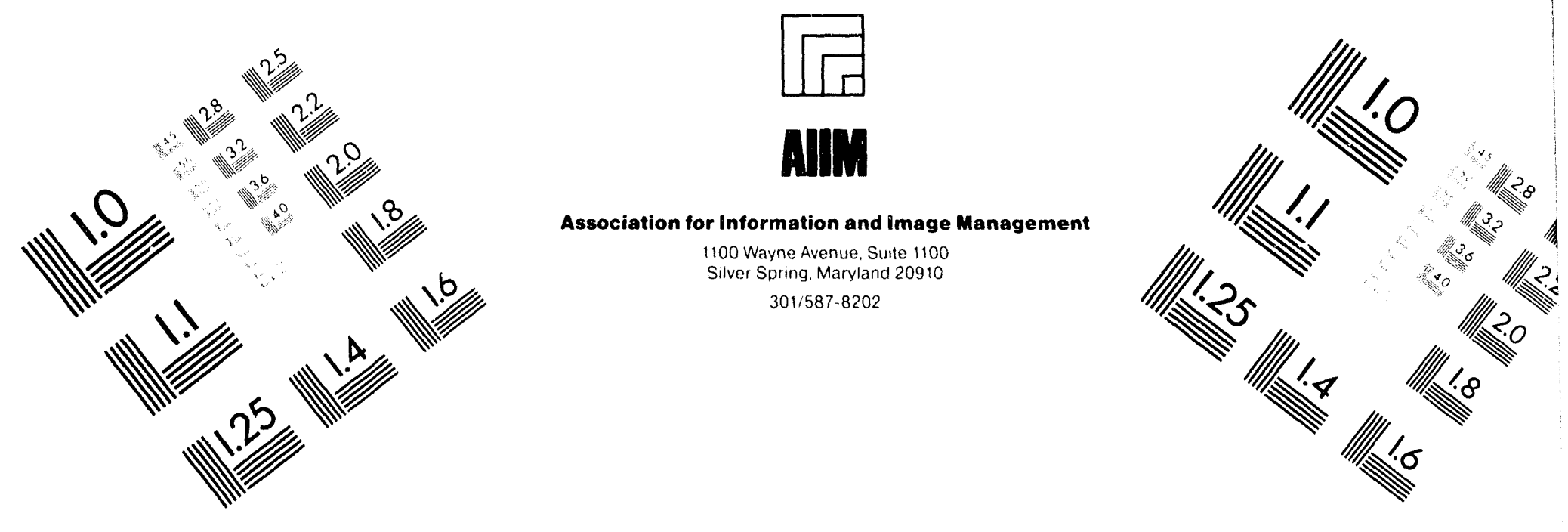

Centimeter

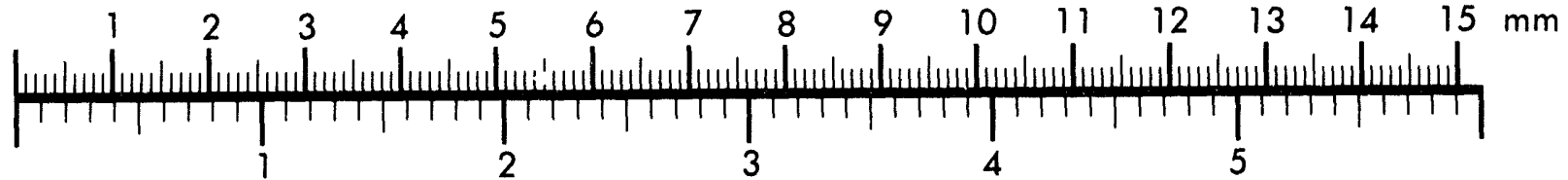

Inches
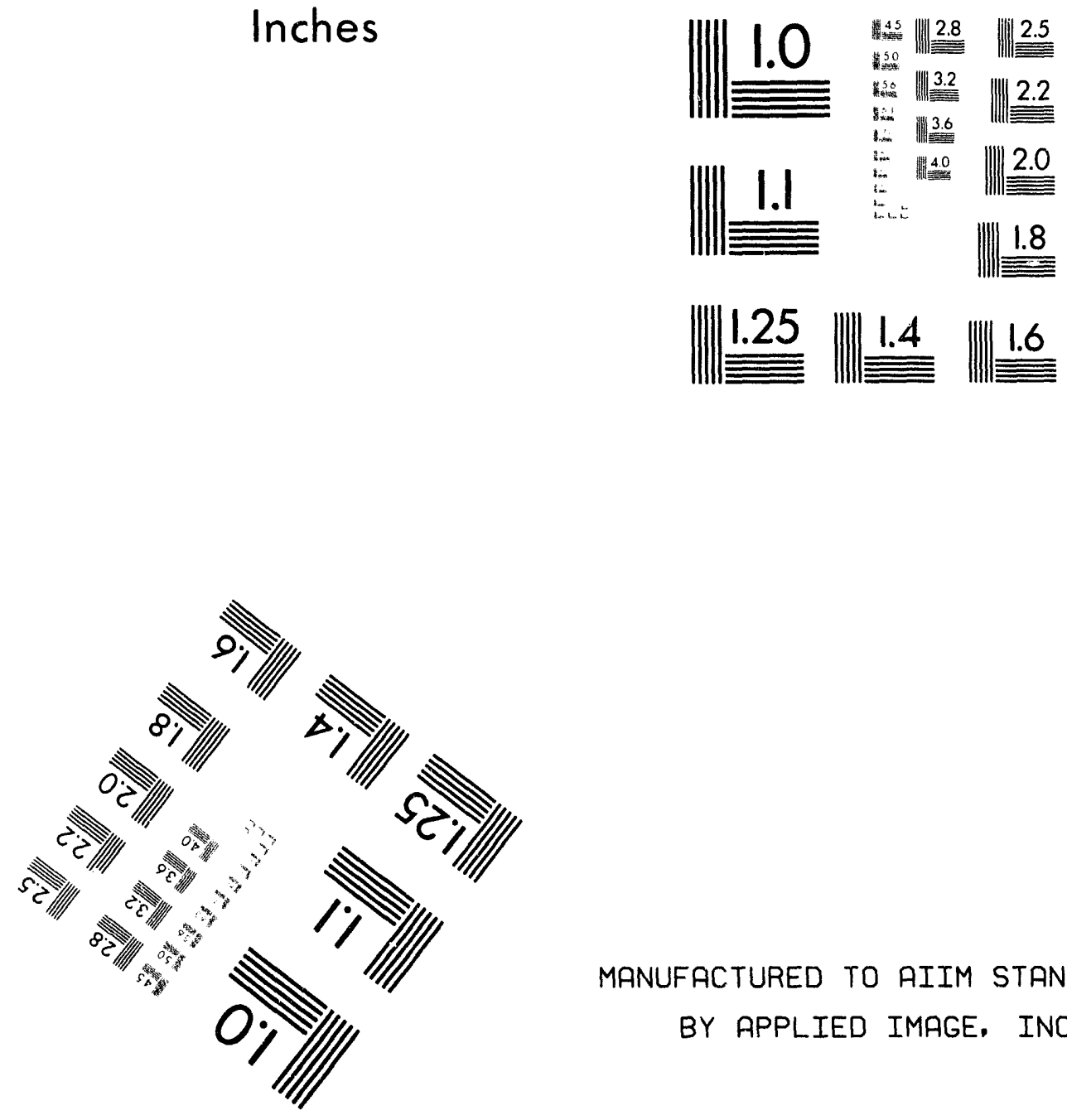

MANUFACTURED TO AIIM STANDARDS

BY APPLIED IMAGE, INC.

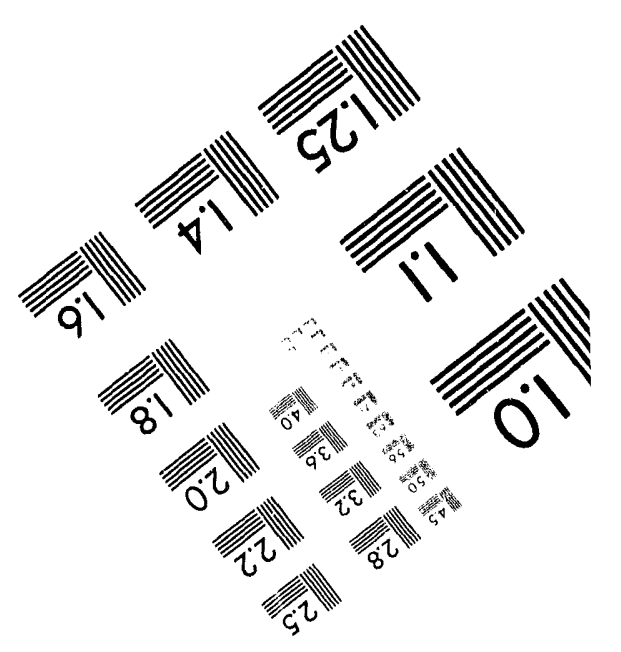



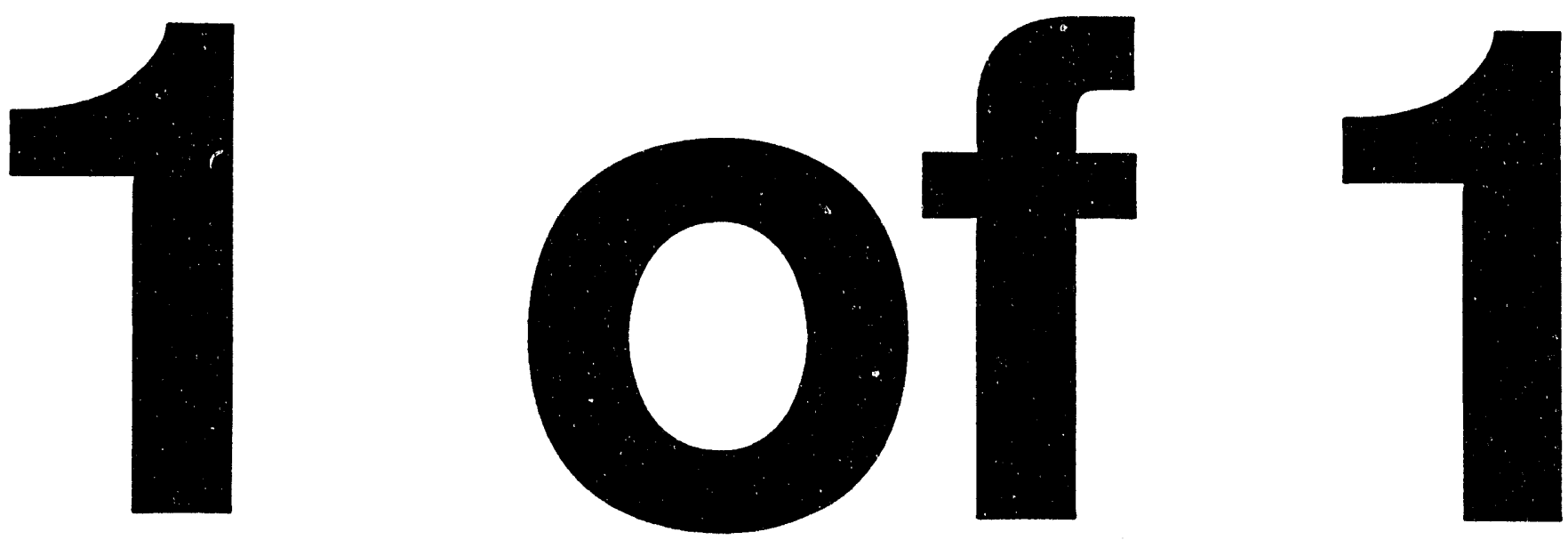


\section{FUNCTIONAL CHECK OF TELESCOPING TRANSFER PUMPS}

by

Sharpe, C. L.

Westinghouse Savannah River Company

Savannah River Site

Aiken, South Carolina 29808

DOE Contract No. DE-AC09-89SR18035

This paper was prepared in conneciion with work done under the above contract number with the U. S.

Department of Energy. By acceptance of this paper, the publisher and/or recipient acknowledges the U. S.

Government's right to retain a nonexclusive, royalty-free license in and to any copyright covering this paper, along with the right to reproduce and to authorize others to reproduce all or part of the copyrighted paper.

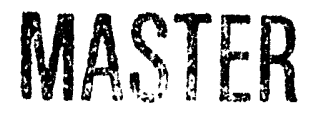




\section{DISCLAIMER}

This report was prepared as an account of work sponsored by an agency of the United States Governmeat. Neither the Uaited States Government nor any agency thereof, nor any of their employees, makes any warranty, express or implied. or assumes any legal liability or responsibility for the accuracy. completeness, or usefulaess of any information, apparatus, product, or process disclosed, or represents that its use would not infringe privately owned rights. Reference hereia to any specific commercial product, process, or service by trade name, trademark. manufacturer, or otherwise does not necessarily constitute or imply its endorsement, recommendation, or favoring by the United States Government or any ageacy thereof. The views, and opiaions of authors expressed berein do not necessarily state or reflect those of the United States Government or any ageacy thereof.

This report has been reproduced directly from the best available copy.

Available to DOE and DOE contractors from the Office of Scieatific and Technical Information. P. O. Box 62. Oak Zidze. TN 37831; prices available from (615) $576-8401$.

Available to the public from the National Technical Information Service. U. S. Deparment of Commerce, 5285 Por Royal Rd. Spriagfield. VA 22161 
WSRC-TR-94-0226

Revision 0

Publication Date 4-29-94

FUNCT IONAL CHECK OF TELESCOPING TRANSFER PUMPS (U)

C. L. Sharpe 
WSRC-TR-94-0226

Revision 0

Keywords: Telescoping Transfer Pump

Functional Check

Classification

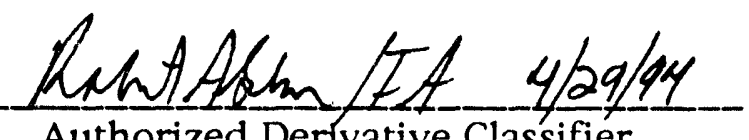

Authorized Derivative Classifier

\title{
FUNCTIONAL CHECK OF TELESCOPING TRANSFER PUMPS (U)
}

\author{
C. L. S'iarpe
}

Publication Date 4-29-94

Cls Shaype

C. L. Sharpe, Principal Engineer, HLW Engineering

Date: $4-2-9-9 q$

M.

M. J. Dalmaso, Technical Reviewer, SRTC-IWT

Date:-4/29/94

C. feldi L

Eloy Saldivar, Manzger, HLW Engineering

Date:_ftes/24

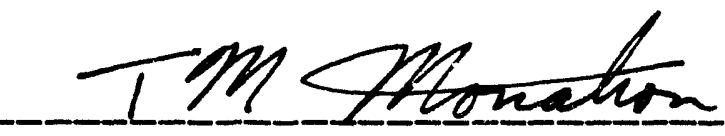

T. M. Monahon, HLW Engineering

Date: $4-29-94$ 
Functional Checks of Telescoping Transfer Pumps WSRC-TR-94-0226

Abstract:

Activities are defined which constitute a functional check of a telescoping transfer pump (TTP). This report is written to the Procedures group of HLW and particularly applies to those TTP's which are the sole means of emergency transfer from a HLW waste tank. These tanks are identified in WSRC-TR-94-645. 
Functional Checks of Telescoping Transfer Pumps WSRC-TR-94-()226

\section{TABLE OF CONTENTS}

Abstract

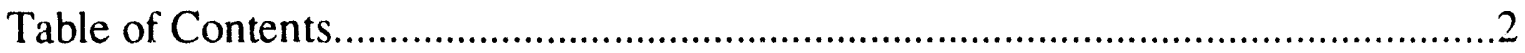

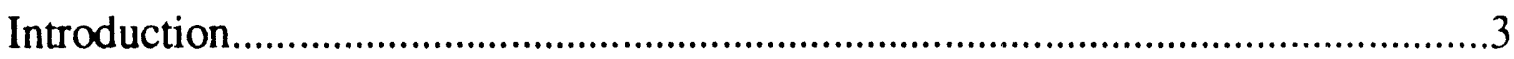

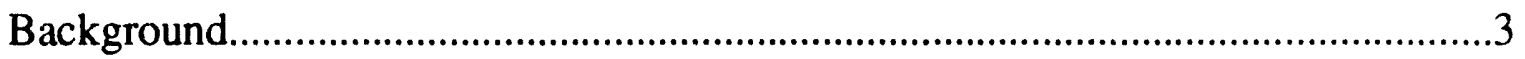

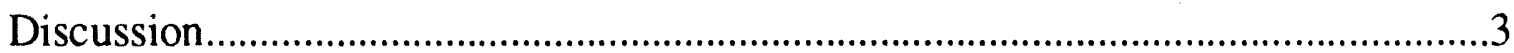

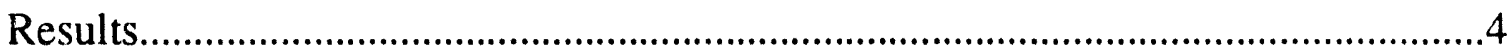

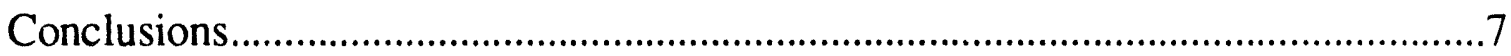

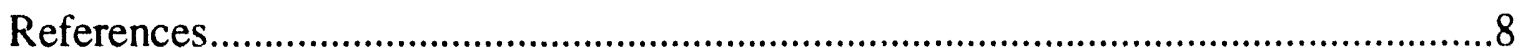

Figure 


\section{INTRODUCTION}

The purpose of this report is to provide the Engineering Criteriat to perform functional checks of Telescoping Transfer Pumps which are also serving to perform emergency transfer capability from High Level Waste tanks.

\section{BACKGROUND}

WSRC-TR-93-645 evaluated the ability of the equipment in HLW waste tanks to meet the requirements for emergency transfer as specified in Technical Standard DPSTS-241-1.01. Most tanks have transfer jets for emergency transfer. Six tanks rely on telescoping transfer pumps. One pump has not been operated since about 1985, others were last used in 1987,1989 , and 1992. Two pumps are more recently installed but have not been operated. A need was identified to perform periodic functional checks on these pumps to assure their ability to serve as emergency transfer equipment.

\section{DISCUSSION}

The pumps are all Hazelton Model 2 1/2" AN Special VSB manufactured by Barrett Haentjens Co. of Hazelton, Pennsylvania. They are vertical, line shaft, single stage centrifugal pumps with top mounted motor and water filled column. They have a discharge pipe separate from the column with a packing gland which allows the discharge pipe to telescope and the pump to be adjusted within limits relative to the tank bottom. They were installed for waste removal or more recently for transfer of processed waste. Most have variable frequency drives and can operate up to $2265 \mathrm{rpm}$. The design point is $100 \mathrm{gpm}$ at $215 \mathrm{ft}$. of head. They require a supply of bearing water for the water filled column to lubricate and cool the graphite sleeve bearings. The earliest pumps had only a clearance type seal at the bottom of the column and consumed roughly $2 \mathrm{gpm}$ when the column was filled. The present pumps have mechanical seals and should consume only about $300 \mathrm{ml} / \mathrm{min}$. on the top packing. A schematic of the pump is shown in Figure 1. 
Functional Checks of Telescoping Transfer Pumps WSRC-TR-94-0226

When slurry pumps (mixer pumps) were equipped with bottom seals and top packing, the result was contaminated column water and ultimately contamination of the pump and tank tops by migration up the column and leakage at the packing. This problem was not believed to exist in TTP's because of design differences in the seal and column. However recent surveys have found contamination on TTP tops from undetermined sources. Because of these concerns and uncertainties, work around the TTP's, particularly maintenance activities, should be performed as if the column water were contaminated until proven otherwise.

The philosophy for performing a functional check is to first check the components and auxiliary systems and then to check the pump by actually performing a transfer of sufficient quantity to allow a determination that the transfer occurred. Should circumstances exist where an actual transfer is not justified, the checkout of components up to the point of actually transferring product could be considered a functional check with management and engineering approval. The probability of a pump not functioning if all components and systems are funtional is extremely low.

\section{RESULTS}

The purpose of this section is to provide the Engineering Criteria to the HLW Procedures group to enable procedures to be written for executing functional checks on individual tanks.

\section{Summary:}

1-Perform functional check annually

2-Individually check pump components and auxiliary systems

3-Perform selected maintenance seven year cycle

4-Run pump and transfer if possible.

\section{Details:}

To assure reliability of the pump and its auxiliary systems it is recommended that functional checks be performed annually. The activities listed below in groups 1 through 4 are component or auxiliary system checks. Group 5 is a pump check. Group 6 is a shutdown check with review for potential problems or procedure upgrade. 
Functional Checks of Telescoping Transfer Pumps WSRC-TR-94-0226

1 -Drives, motor, and coupling.

A-Inspect and check out the electrical drives.

B-Verify electrical connections.

C-Meg motor

D-Verify correct motor rotation with coupling disconnected.

E-Verify speed control is functional is so equipped.

F-Take vibration measurements-motor only. Measure and record two axes on upper and lower motor bearings and one axial measurement.

Limit- $0.1 \mathrm{in} / \mathrm{sec}$ velocity. If over $0.1 \mathrm{in} / \mathrm{sec}$ velocity, contact engineering for guidance.

G-If over seven years since motor overhaul, send motor to motor shop for replacement of bearing grease and motor overhaul if needed.

$\mathrm{H}$-Inspect rubber coupling inserts for deterioration and cracks. If cracked or if over seven years old, replace inserts.

2-Bearing water system.

A-Inspect bearing water tank for cleanliness and bacterial growth. If needed, perform cleaning and flush of lines.

B-Replace bearing water filters.

C-Fill tank and verify operability of both flowmeters.

D-Fill column and estimate amount of water required by using difference in tank level and record data.

E-Record steady state column water usage rate using flowmeter. If flow exceeds meter limit, contact engineering for guidance. All installed pumps should have bottom mechanical seals and the flow rate should be roughly $300 \mathrm{ml} / \mathrm{min}$. Record and discuss the flow rate with engineering.

F-Observe the top packing leak. Treat the packing leak as if it were contaminated. Have the packing leak surveyed and record and discuss results with engineering. If the packing leak is more than a very small stream, remove pressure from column and discuss with engineering. Packing replacement may be necessary. If packing replacement is needed refer to Procedure HLWM 15200 (revision may be needed if packing replacement is not included) G-Check tightness of all bearing water fittings. Do not overtighten. Record findings. Treat surfaces as contaminated. 
3-Piping, valves, and jumpers.

A-Follow applicable transfer procedures for piping alignment.

B-Verify that the pump discharge valve and the two flush valves are operable and show no signs of external leakage. If the valves are not operable, replacement of seals or valve components may be necessary. Contact engineering for guidance and instructions for repair.

C-Connect flush water to the flush valve on the pump side of the pump discharge valve and flush approximately 100 gallons of water through pump to verify piping and casing is open. Discharge valve is to be closed.

D-Inspect discharge connector for signs of leakage. Replacement of discharge connector gasket may be necessary. Contact engineering for guidance.

4-Thrust bearing, shaft, and impeller.

A-With coupling disconnected, rotate shaft by hand from top coupling and observe for free rotation and freedom from interference or internal scrubbing. Note: Added force up to about 80 $\mathrm{ft}$-lbs. torque (estimated) may be needed to start initial rotation. $\mathrm{Be}$ alert for increased packing flow when rotated. Treat the coupling and other surfaces and the water as if it were contaminated.

B-If thrust bearing grease is over seven years old, remove and clean thrust bearing, inspect bearing for spots or wear, and replace grease. If bearing shows damage, replace bearing also. Follow procedure in applicable BPF and applicable steps in HLWM 15206 for motor removal.

B-Set the impeller clearance at $0.035 "$ following the applicable steps in procedure HLWM 15206.

C-Align motor to pump following applicable steps in HLWM 15206. D-Connect coupling 


\section{5-Pump operation.}

A-Follow applicable operating procedures for the specific tank. $B$-Do not operate pump against a closed valve. If no transfer is possible for administrative reasons, then the steps taken to this point may be accepted as the functional check out with management and engineering approval. $C$-If a transfer can be made, then transfer about 1000 gallons and verify transfer via tank level changes. This will be about a $10 \mathrm{~min}$. transfer.

D-Record two-axis vibration at upper and lower motor bearings and thrust bearing and an axial reading. Note possible time limitation. E-Note pac':ing leakage during operation. If excessive (more than a very small stream), record observation and discuss with engineering. It will not be possible to make a packing adjustment during a short run, but plans for future maintenance should be developed. Treat the water and surfaces as contaminated.

\section{6-Post operation inspection and evaluation.}

A-After shutdown, inspect the discharge connector in the riser and the discharge valve and two flush valves for signs of leakage. If leakage is indicated, notify engineering. Replacement of discharge connector gasket may be needed. Contact engineering for guidance. B-Secure the drives and bearing water per operating procedures. C-Close the discharge valve, flush the pump with about 100 gallons of water and flush the transfer line with the amount specified by the system cognizant engineer.

D-Review the functional check with the cognizant system engineer and the HLWE pump technical resource (Sharpe)

\section{CONCLUSIONS}

The activities described in this report and the documents listed in Reference 1 are the basis for procedures to perform functional checks of telescoping transfer pumps. 
Functional Checks of Telescoping Transfer Pumps WSRC-TR-94-0226

\section{REFERENCES}

1-WSRC-TR-93-645, "Tank Farm Emergency Transfer Capabilities Evaluation(U), J. A. Pike et al. The affected facilities are Tanks $17,18,21,22,48,49$, and 42 .

2-Program Commitment Management System -(PCMS) 93426

Step 1 Develop Engineering Criteria Tanks 17, 18, 21, 22, 48, 49 -(PCMS) 93433

Step 1 Develop Engineering Criteria Tank 42

-(PCMS) 93480

Step 2 Develop Procedures Tanks 17, 18, 21, 22, 48, 49 -(PCMS) 93484

Step 2 Develop Procedures Tank 42

3-BPF 213350 TTP Tanks $17,18,21,22$

4-BPF 215652 TTP Tank 42

5-BPF 215216 TTP Tank 48

6-BPF 215647 TTP Tank 49

7-HLWM 15200 Packing Adjustment on Barrett Haentjens

Telescoping Transfer Pumps

8-HLWM 15206 Motor replacement on Barrett Haentjens Telescoping Transfer Pumps 
$\because \therefore \quad \therefore$

\section{BARRETT HAENTJENS TELESCOPING TRANSFER PUMP}

Used in $F$ and $H$ area tank farms for transfers of waste slurries from waste storage tanks to in-tank waste processing facilities, the DWPF and Saltstone.

$460 \vee$ electrical supply

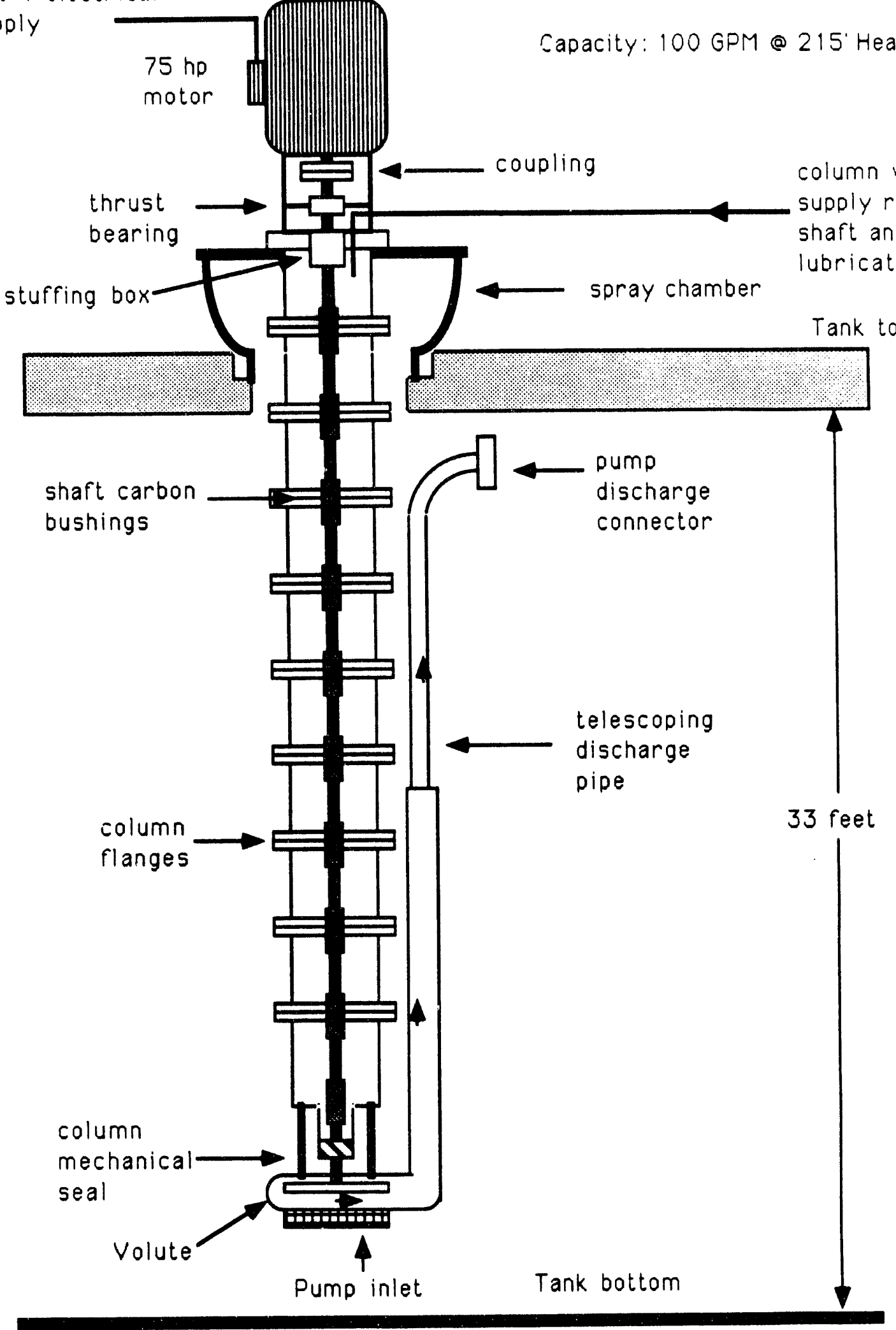


DISTRIBUTION

G. T. Wright, 703-H

T. J. Lex, 719-4A

W. B. Boore, 703-8C

J. W. French, 703-H

H. M. Handfinger, 704-56H

B. E. Long 703-21C

R. R. Salmon $703-13 \mathrm{C}$

D. Hoffman $703 \mathrm{H}$

J. A. Pike $703 \mathrm{H}$

R. S. Tran $707 \mathrm{H}$

W. E. Phillips 241-152H

T. C. Hsu $703 \mathrm{H}$

J. R. Chandler $703 \mathrm{H}$
A. J. Tisler 241-102H
P. S. Mukherjee $707 \mathrm{H}$
R. Salizzoni, $707 \mathrm{H}$
W. C. Clark, 241-119H
B. L. Lewis, 703-8C
E. Saldivar $703 \mathrm{H}$
T. L. Ortner $241-152 \mathrm{H}$
K. C. Sibley 241-119H

J. P. Wood 704-56H

B. R. Hess 241-102F

J. E. Marra, $703 \mathrm{H}$

J. R. McCullough 241-121H

L. S. Dee 703-6C

T. L. Goodman 241-121H

B. G. Croley 241-120H

T. M. Monahon 703H

W. L. Tamosaitis 773A

J. Y. Baladi 730B

M. J. Dalmaso 676T

File RM., 77, 703-H

File Code: 166.6

Tech. Info. Mgt., 703-43A(4 copies) 

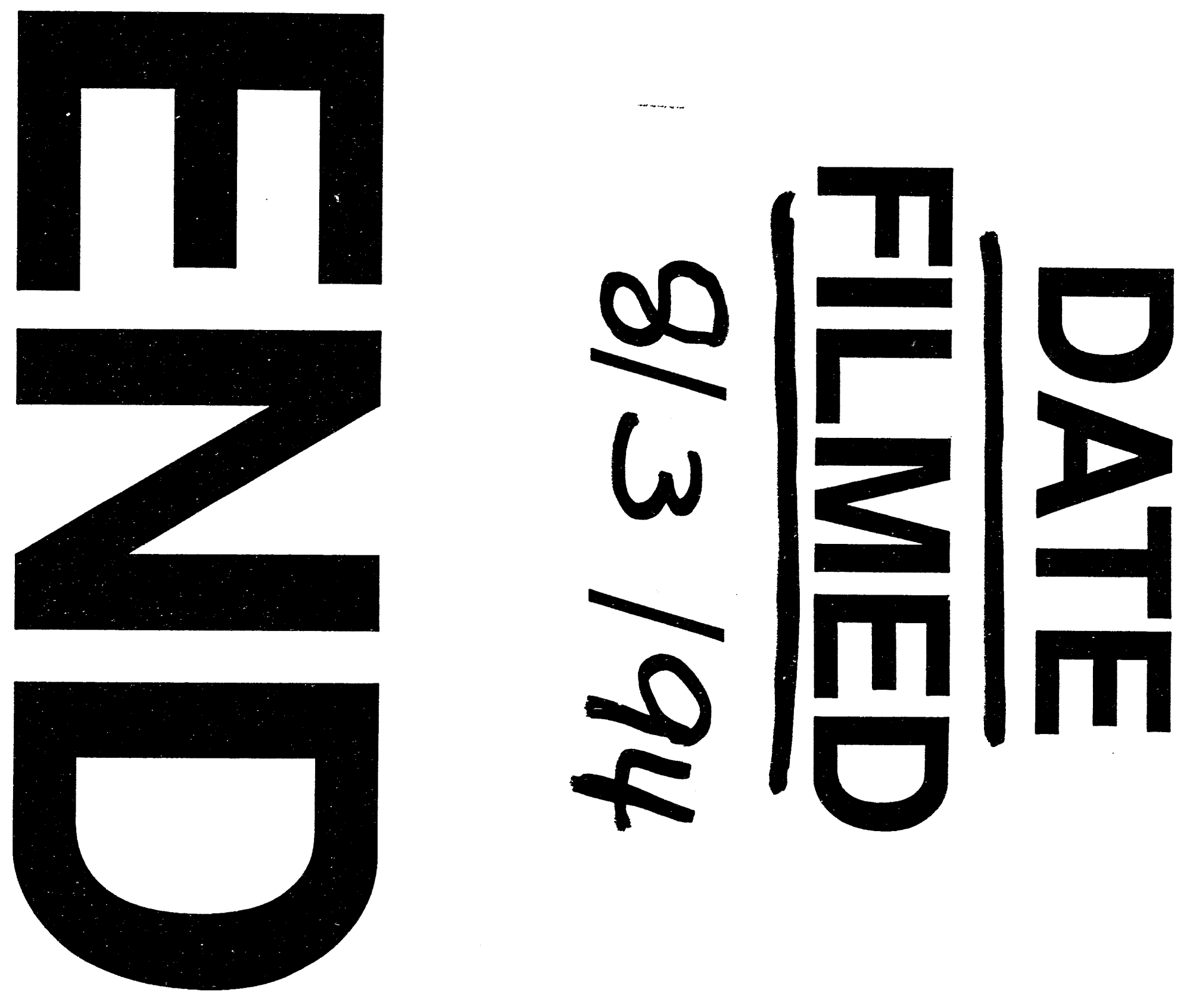

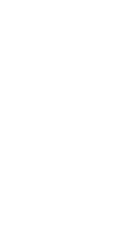

.
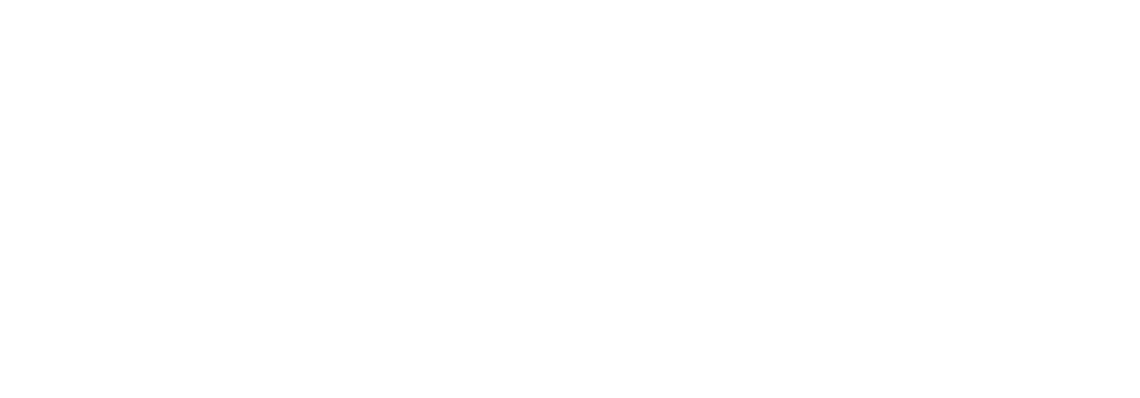

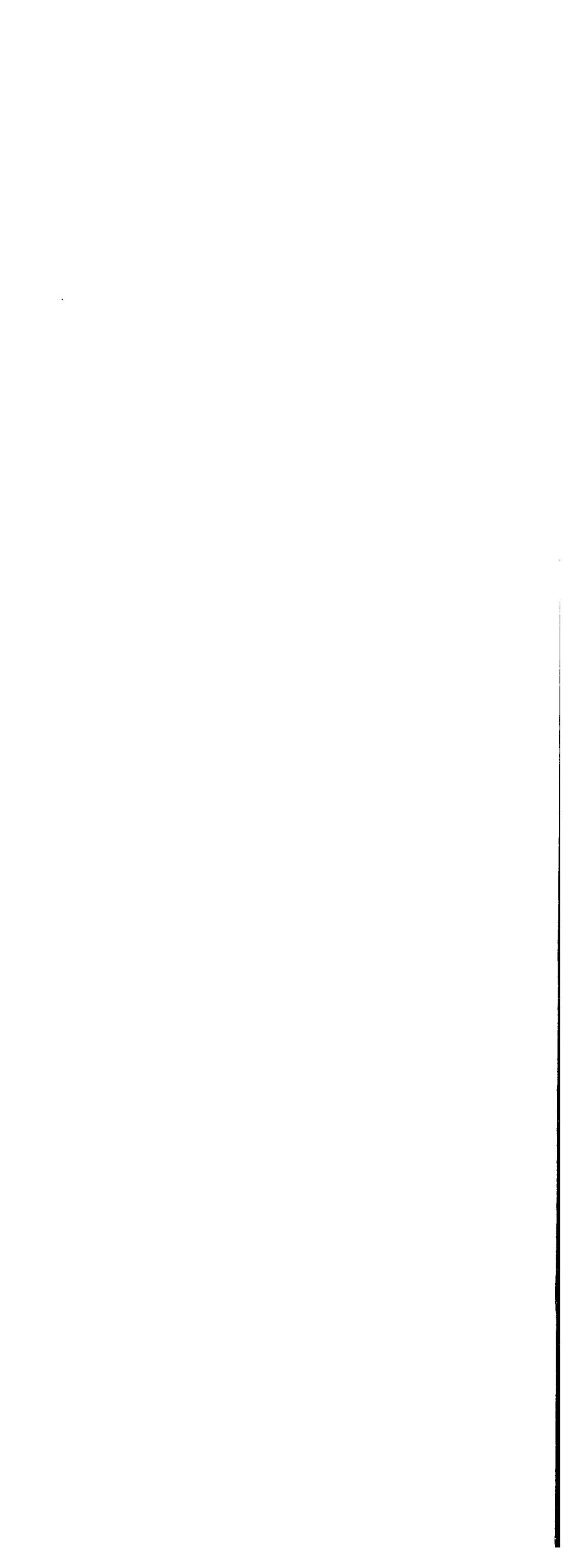

